British Journal of Education

Vol.8, Issue 3, pp.76-96, March 2020

Published by ECRTD- UK

Print ISSN: ISSN 2054-6351

Online ISSN: ISSN 2054-636X

\title{
PERCEPTION OF PUBLIC BASIC SCHOOL TEACHERS ON THE FACTORS INFLUENCING TEACHER ATTRITION AND RETENTION IN THE ATIWA DISTRICT IN THE EASTERN REGION OF GHANA
}

\author{
${ }^{1}$ Joseph Bentil, ${ }^{2}$ Sakina Acquah (Ph.D), and ${ }^{3}$ Stephen Osei Akyiaw \\ 1, 2, \&3 (University of Education, P. O. Box 25, Winneba, GHANA) \\ Corresponding email: joseph_bentil@yahoo.com
}

\begin{abstract}
This study investigated the factors influencing teacher attrition and retention in public basic schools in the Atiwa District in the Eastern Region of Ghana. A descriptive survey design was used in the conduct of the study where through proportionate stratified random and convenience sampling techniques, 515 teachers were sampled and participated in the study. The instruments included a structured questionnaire and semi-structured interview guide. Data collected were analyzed using both descriptive statistics like mean and standard deviation as well as inferential statistics such as multiple regression with the aid of Version 22 of SPSS. The qualitative data were analyzed through the thematic approach. The study revealed that the teachers identified remuneration and conditions of service factors to predominantly influence their quit intentions more than school environment factors and personal factors. The study showed that retention strategies such as improved salary and remuneration, provision of housing scheme, regular in-service training for teachers, scholarships for further studies, improved classroom environment and teacher involvement in decision making to be likely to boost their retention. Generally, it was revealed that teachers demographic variables such as marital status, years of teaching experience and level of teaching significantly predicted their quit intentions. It was further revealed that there was a positive correlation between the predictors (sex, age, rank, academic qualification, marital status, teaching experience, and level of teaching) and retention strategies as these demographic variables contributed significantly to retention strategies. It was therefore recommended that the Ghana Education Service through the Atiwa Education Directorate should ensure improved remuneration and conditions of service and school environment should be improved since these are among the top reasons discovered as being behind teacher turnover.
\end{abstract}

KEYWORDS: Teachers, attrition, retention strategies, demographic variables

\section{INTRODUCTION}

In educational institutions, teachers are considered as priceless assets in the realization of educational goals. Therefore, the success of any country's educational policy is contingent on its ability to recruit and retain its teachers. Accordingly, scholars like Oloruntegbe (2011) and Okeke (2004) observed that teacher has assumed a very cardinal in the field of study due their unique role they play as nation builder. In essence, teachers are seen as the pivot around which the attainment of educational goals revolves. Ngala (2010) and Charlton and Kritsonis (2010) 
British Journal of Education

Vol.8, Issue 3, pp.76-96, March 2020

Published by ECRTD- UK

Print ISSN: ISSN 2054-6351

Online ISSN: ISSN 2054-636X

opined that the quality and strength of teachers define the effectiveness of the educational sector. Likewise, Owolabi (2007) noticed that there is no one who has more potential for touching the personal, social, and intellectual lives of children than do caring and dedicated teacher. The above views have endorsed the claim that success would elude educational institutions if efforts are not made in attracting and recruiting teachers into the classrooms.

However, there is growing concerns across the world that educational sectors worldwide are confronted with the challenge of teacher transfers and attrition which militates against efforts at retaining teachers in schools. For instance, across the United States of America, it was reported that approximately half a million teachers leave their schools each year, and 84 percent of the teacher turnover is due to transfers between schools (Alliance for Excellent Education, 2008). Levy (2012) also reported that out of the 4,206 teachers in the District of Columbia Public Schools, $43 \%$ left the district within two years while $56 \%$ left within five years. Teacher attrition has grown by 50 percent over the past fifteen years, and the national teacher turnover rate spans between 16.8 and 20 percent, and this cost the U.S. school systems more than $\$ 7$ billion a year (Kain, 2011; Hernandez, 2007). Similar developments have been reported in Africa as well. Amongst the twelve districts of Nyanza Province in Kenya, Suba district teachers have been leading in the number of transfer requests (Ariko, 2009). Based on these reports, it is evident that both developed and developing countries are struggling with teacher retention in their schools.

In Sub-Saharan Africa, contemporary teacher attrition rates are believed to range between 5 and 30 percent in different countries (World Bank, 2007). These views sustain the truism that teacher attrition is a worldwide phenomenon that necessitates critical attention from all stakeholders of education. The Ghana Education Service (GES) estimated that about 10,000 teachers leave the schools yearly for various reasons (GNAT \& TEWU, 2009). Besides, Ghana Business News Report (2013) disclosed that about 33,185 teachers quit the teaching profession in search of other jobs. A national survey by Quansah (2003) reported a shortage of 40,000 trained teachers in basic schools and discovered that 24,000 of these vacancies have been filled by untrained personnel. Additionally, Mireku (2002) illustrates that between 1988 and 1998, Teacher Training Colleges now Colleges of Education in Ghana produced 54,100 teachers and were posted to the basic school system. Avoke (2013) argued that there is no data on how long the teachers may have remained in these postings or if they actually took them up. From the foregoing discussion, it is obvious that over the past decades, a considerable number of studies seeking to discover reasons for this brain drain have been done and this phenomenon keeps happening.

Previous studies have proven that lack of employee retention leads to high organizational costs and low performance. Jackson and Mathis (2006) noted that organizations that are unable to retain their employees have to spend lots of money and other resources to attract, recruit and train new employees which makes recruiting new employees more expensive than retaining the existing ones. To this end, Dibble (1999) categorized the cost of turnover as direct and indirect. Direct costs include replacement, hiring and selection process, expenses of temporary staff, and the wasted time, and indirect costs include decline in staff's morale, extra pressure on remaining 
British Journal of Education

Vol.8, Issue 3, pp.76-96, March 2020

Published by ECRTD- UK

Print ISSN: ISSN 2054-6351

Online ISSN: ISSN 2054-636X

employees, decline in the quality of product/ service, costs of learning, and the lost knowledge from the organization. Implicitly, teacher retention should therefore be the concern of educational stakeholders at all times if they desire to realize improved academic performance and the achievement of school and educational goals.

Extant research findings documented differing factors that account for teacher attrition. For instance, Aglomasa and Avoke (2013) observed that teachers leave the profession because they are dissatisfied with their salaries. Consistent with this revelation, Buchanan, Prescott, Schuck, Aubusson and Burke (2013) unveiled that inadequate induction programs, poor conditions of service and a growing salary gap between teachers and other college graduates as sources of teacher turnover. Scholars believe working conditions may be more important than salary as a factor in teacher turnover (Allen, 2005; \& Horng, 2005). Brok, Wubbels and Tartwij (2017) and Hong (2010) provided evidence that working conditions and inadequate salaries play a crucial role in teacher choices to change schools or leave the profession. The findings from Mulei, Waita, Mueni, Mutune and Kalai (2016) concluded that poor salaries, poor working environment, and indiscipline towards teachers are the major factors influencing teacher attrition. In essence, improved remuneration and enhanced conditions of service factors quality boost teacher retention.

Another factor that influence teacher turnover is the dilapidated school and classroom environment. Several studies relating to teacher work place and its impact on attrition and retention have revealed interesting results. Darling-Hammond and Sykes (2003) amplified this claim when they argued that working conditions play a crucial role in teacher choices to change schools or leave the profession. Smith (2014) encapsulated that school environment factors such as heavy workload, large classes, time pressure, stress and burnout as well as poor relationships in the school to be the reasons teachers quit teaching. Luekens, Lyter and Fox (2004) in their study in the United State found that among teachers nationwide who left the profession and reported working in non-teaching positions, more than half stated the manageability of their workload, opportunities for professional advancement, autonomy or control over their own work, and general working conditions were better in their current non-teaching positions. In their reviews and analyses of national teacher turnover rates, both Allen (2005) and Ingersoll (2001) concluded that schools with greater teacher autonomy also have lower turnover rates.

On teacher personal factors that predict turnover, Buchanan, et al., (2013) identified in their study that snags to adjust to teaching demands, difficulties in managing social relations, and perilous or unhealthy school climate as the personal reasons underpinning attrition. The authors further revealed that lack of collegiality and support of beginning teachers, student disciplinary challenges, poor working conditions, lack of teaching resources, no opportunities for professional learning, high workload, and social isolation are among the personal factors teachers ascribed to quitting teaching. Other scholars supported the personal-related factors influencing teacher attrition when they disclosed the persistent psychological demands imposed on teachers, negative social relations with colleagues, negative student behavior, lack of passion to teach, lack 
British Journal of Education

Vol.8, Issue 3, pp.76-96, March 2020

Published by ECRTD- UK

Print ISSN: ISSN 2054-6351

Online ISSN: ISSN 2054-636X

of respect and recognition, relationships and pregnancy (Harmsen, Helmz-Lorenz, Maulana, \& van Veen, 2017; Pillen, 2013, \& Candle, 2010) are among the personal factors that trigger teacher attrition. Therefore, in this this study, three factors were considered. Thus, remuneration and conditions of service, teachers' personal and school environment related factors were explored to ascertain how they predict teacher attrition.

Several researchers have investigated the effect of teachers' demographic variables sex, age, rank, academic qualification, marital status, teaching experience, and level of teaching and how it predicts attrition. Makisio (2016) discovered that the retention of teachers was influenced significantly by gender, age, academic qualification, and years of teaching experience. This result implied the likelihood of teacher retention is contingent on these variables. Confirming this finding, Riggs (2013) observed that female teachers have higher stay intentions than male teachers. Efanga, Ikpe and Idante (2014) discovered that gender of teachers significantly affects their retention motives with males being more likely to quit teaching. Likewise, Nkang (2004) and Efanga (2007) discovered a statistically significant difference between gender and teacher retention motives with female teachers likely to stay longer than their male counterpart. However, Strydom, Nortje, Beukes, Esterhuyse, and Westhuizen (2012) and Otube (2004) observed that there is no significant difference between gender and teachers retention.

On age, previous studies have found a statistically significant difference between age and retention intentions of employees (Borman \& Dowling, 2008 \& Ahuja, Chudoba, Kacmar, McKnight \& George, 2007). Contrarily, Crossman and Harris (2006), George, Louw and Badenhorst (2008) and Otube (2004) report that there was no statistically significant difference between age and teachers' retention. With respect to academic qualification, Dehaloo (2011) found a statistically significant difference between teachers' academic qualification and retention. Nevertheless, George et al., (2008) discovered no statistically significant difference between teachers' age and retention. Nkang (2008) disclosed a statistically significant difference between years of experience and teachers willingness to stay in the teaching profession. Departing from Nkang's (2008) finding, Efanga et al., (2014) found that there was no significant statistically significant difference between years of teaching experience and teacher retention.

The effect of level of teaching and teacher retention has been a subject of investigation by researchers. For example, Stinebrickner (2002) discovered that the level teachers teach does not have a significant impact on the probability that teachers will quit teaching. However, Chandler, Luekens, Lyter and Fox (2004) discovered a statistically significant difference between teachers' level of teaching and retention. Shaheen and Mahmood (2016) revealed in their study that gender, location, qualification, and level at teaching were significant towards the progression of burnout whereas job status, marital status, and age were found non-significant on prevalence of burnout. However, the authors concluded that demographic variables investigated were not conclusively determinants of burnout. The results of the above studies suggest that conflicting results exist on the influence of demographic factors on teacher retention. Due to the lack of agreement in the results, there is the need for further investigation on the extent to which these 
British Journal of Education

Vol.8, Issue 3, pp.76-96, March 2020

Published by ECRTD- UK

Print ISSN: ISSN 2054-6351

Online ISSN: ISSN 2054-636X

factors affected teacher retention. Therefore, the influence of sex, age, academic qualification, experience, marital status, and level of teaching were explored in this study.

To resolve the teacher retention problem, countries and researchers have explored varied strategies that could be implemented to curtail attrition. For instance, Mulkeen (2005) discovered in Mozambique that there is a system of financial bonuses for teachers who locate in rural areas and teachers who teach two shifts. The author observed that financial incentives in addition to non-monetary incentives have had positive impact on teacher retention in Africa. Mulkeen (2005) reported that in 2001, the Uganda government introduced a hardship allowance of $20 \%$ of basic salary for hard-to-reach areas. In another report, Ingersoll (2001) noted that the provision of retention bonuses has been successful in minimizing teacher transfer requests. MChia (2013) discovered that improving working conditions, increasing salary and other benefits, provision of housing schemes for teachers were among the retention strategies put forward to retain teachers. Consistent with this revelation, empirical studies from Makisio (2016) and Northouse (2013) also, found that annual salary increase, improvement of teachers working conditions, provision of career development opportunities, apposite leadership style and swift and regular promotions of teachers have been advanced in trying to get teachers in the classroom. In Ghana, study leave with pay, $15 \%$ retention premium, and recent and yet to be implemented allowances for deprived area teachers are intended to retain teachers. Despite these strides, available literature has disclosed that the challenge of teacher retention still persist (Buchanan, et al., 2013 \& McInerney, Ganotice, King, Marsh, \& Morin, 2015). Accordingly, studies need to be conducted in specific contexts to determine which factors and retention strategies are needed to retain teachers in the schools. It is against this backdrop that this study is carried out.Available literature has documented that the teaching profession is noted for high teacher transfers which is inimical in realizing school and educational goals as it demoralizes teachers, and lead to high costs of recruitment. Similar scenario has been observed in the Atiwa District as illustrated in Figure 1.1.

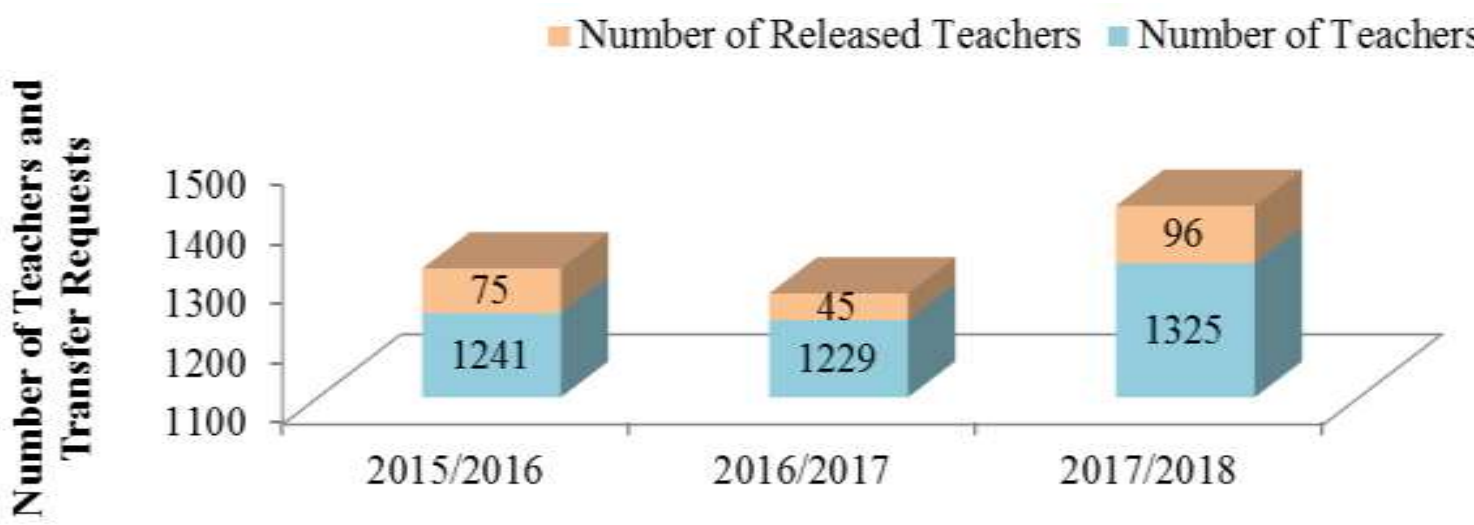

Academic Years

Figure 1. 1 Trends in Teacher Release

Source: Atiwa District Education Office, 2018 
British Journal of Education

Vol.8, Issue 3, pp.76-96, March 2020

Published by ECRTD- UK

Print ISSN: ISSN 2054-6351

Online ISSN: ISSN 2054-636X

It could be observed from Figure 1.1 that teacher transfer release have been increasing in the Atiwa District. In 2015/2016 academic year, 75 out of 1,241 teachers representing about $6.5 \%$ teachers were released. In 2016/2017 academic year, teacher release took decreased as 45 out 1,229 of the teachers were released. However, teacher released increased in 2017/2018 as 96 out of the 1,325 were released representing about $4 \%$ over the previous year. Teacher released demand were 6.5\%, 3.3\% and 7.3\% in 2015/2016, 2016/2017 and 2017/2018 academic years respectively. From these statistics, it could be seen that the rate at which teachers demand release stands at $5.7 \%$ over the period under review. Even though the demands of teacher transfer are high in the District, no empirical studies have been conducted to ascertain the factors that account for this situation. Therefore, it is pertinent that the studies are conducted to unveil the factors underlying this phenomenon which is the focus of the study.

The following research questions guided the study:

1. What is the nature of the factors that influence teacher attrition in the Atiwa District?

2. What retention strategies could be used to enhance retention of teachers in public basic schools in the Atiwa District?

3. To what extent does factors (sex, age, rank, academic qualification, marital status, teaching experience, level of teaching) influence teacher attrition in public basic schools in the Atiwa District?

The study also tested this hypothesis:

$\mathrm{H}_{01}$ : Teachers' demographic variables will not statistically significantly predict their perception of the retention strategies.

It is anticipated that the results of the study would inform stakeholders about the state of the factors that influence teacher attrition. This awareness would make them intensify their retention strategies so as to boost teacher retention to achieve desired educational goals. Besides, the students in the district would be the prime beneficiaries of the results of the study in the form of better academic performance. This will occur when the retention strategies are improved to enhance teachers' stay intentions. Finally, the findings of the study will contribute to literature on the existing debates on the reasons underlying teachers' intention to leave the profession, and also serve as a basis for future research.

\section{METHODOLOGY}

A descriptive survey design was used to conduct the study as it aims at identifying problems in current practice with a view to improve practice (Burns \& Grove, 2011). The rationale for the selection of the descriptive survey design was based on the view that it allows researchers to collect large volume of data regarding the opinion of participants on a particular topic, and it is used to investigate the existence of effects and relationships (Leacock, Warrican \& Rose, 2009). In this study, the attrition factors and retention strategies were investigated with the aim of 
British Journal of Education

Vol.8, Issue 3, pp.76-96, March 2020

Published by ECRTD- UK

Print ISSN: ISSN 2054-6351

Online ISSN: ISSN 2054-636X

identifying and applying appropriate strategies to manage teacher attrition. Particularly, the sequential explanatory mixed-method research approach which is consistent with the pragmatic philosophical position was utilized for the study where both quantitative and qualitative data was collected and analyzed. According to Bergman (2008), mixed method approach is an approach to inquiry and research that combines quantitative and qualitative methods into one study in order to provide a broader perspective. Instead of focusing on one type of methodology, mixed methods researchers emphasis the research problem and use all approaches available (quantitative and qualitative) in order to come to a better understanding of the phenomenon under study.

The population for the study comprised of all public basic school teachers in the Atiwa District and the target population included all public basic school teachers who had worked for at least one year in the District. The researchers were convinced that one year was enough for the respondents to vividly provide information on the factors informing their decision to quit teaching as it pertains in their schools. Therefore, the target population was made up of 1325 teachers. A sample size of 515 public basic school teachers representing about $38.6 \%$ of the target population which was deemed representative based on the suggestion by AsamoahGyimah and Duodu (2007) that a sample size of $10 \%$ to $30 \%$ of the population is representative in descriptive survey. The stratified random and convenience sampling techniques were employed in sampling the respondents. The basis for the stratification in this study was gender. From the list, it was discovered that out of the accessible population of 1325, 636 teachers representing $48 \%$ were female teachers while the remaining 689 teachers which constituted $52 \%$ were male teachers. Therefore, in using the same proportions in selecting the 515 participants, 247 females and 268 males were selected for the study. However, out of the 515 teachers, 480 teachers were actually involved in the study representing 93.2\% response rate. Convenience sampling technique was used to select 10 teachers for the qualitative segment of the study which is in agreement with Whitehead and Annells (2007) recommendation of 8-15 participants in qualitative studies. This approach was chosen because the selection of the cases was based on the presence or absence of the respondent at the time of data collection and their willingness to participate in the study (Black, 2009). Therefore, teachers who were available at the time of data collection and agreed to participate in the study were selected.

This study employed a structured questionnaire and a semi-structured interview guide to collect both quantitative and qualitative data. The questionnaire was developed and pre-tested with teachers in East Akim Municipality which shared similar characteristics with those in the study area. Questionnaire apart from being able to obtain data more efficiently, is also economical in terms of time, energy and costs (Sekaran \& Bougie, 2010). Besides, the use of the questionnaire provided an excellent means of measuring views and attitudes in a large population which can, therefore, be generalized to a larger population (Babbie, 2007). The first section of the questionnaire collected data on the demographic characteristics of the teachers while the second section contained items on the remuneration and conditions of service, school environment related and personal related factors influencing teacher attrition. The third section of the 
British Journal of Education

Vol.8, Issue 3, pp.76-96, March 2020

Published by ECRTD- UK

Print ISSN: ISSN 2054-6351

Online ISSN: ISSN 2054-636X

questionnaire collected information on the retention strategies all measured on a 5-point Likerttype scale. Saunders, Lewis and Thornhill (2012) postulates that one of the important aspects of instrument development is checking for its validity and reliability through pre-testing. Therefore, the questionnaire was pre-tested to check its validity and reliability. In this study, reliability was approached as the internal consistencies of the various construct was checked using Cronbach Alpha. Cronbach Alpha coefficient of $0.83,0.85,0.78$ and 0.89 were realized for remuneration and conditions of service, school environment related, personal related factors and retention strategies respectively which are in line with George and Mallery (2003) proposal of Cronbach alpha coefficient of 0.7 or more as being indicative of reliability.

The researchers read through the questionnaires, and removed those that were not answered or poorly answered. Then, the data were coded and entered into the version 22 of the Statistical Product for Service Solution (SPSS) which aided the data analysis. The data were analyzed through descriptive and inferential statistics. Descriptive statistics such as mean and standard deviation inferential statistics included multiple regression. The qualitative data was analyzed thematically as this allowed the researchers to identify, analyze and report themes within the data collected (Braun \& Clark, 2006).

\section{RESULTS AND DISCUSSION}

Research Question One-What is the nature of the factors that affect teacher attrition in Atiwa District?

The aim of this research question was to explore the perception of teachers on the factors that lead to teacher exodus. In this study, the factors were conceptualized as remuneration and conditions of service, school environment related factors, and personal factors, and the results are presented in Table 1.

Table 1: Factors Affecting Teacher Attrition

\begin{tabular}{|c|c|c|c|c|c|}
\hline Factors & $\mathrm{N}$ & Minimum & Maximum & Mean & Std. Dev. \\
\hline $\begin{array}{l}\text { 1. Remuneration and Conditions } \\
\text { of Service Factors }\end{array}$ & 480 & 3 & 5 & 4.54 & 0.36 \\
\hline $\begin{array}{l}\text { 2. School Environment Related } \\
\text { Factors }\end{array}$ & 480 & 2 & 5 & 3.79 & 0.59 \\
\hline Personal Factors & 480 & 2 & 5 & 3.73 & 0.61 \\
\hline Overall Factors & 480 & 3 & 5 & 3.94 & 0.42 \\
\hline
\end{tabular}

Source: Survey Data, 2019

The results in Table 1 revealed that teachers rated highest on remuneration and conditions of service factor $(M=4.54, S D=0.36)$ than the school environment related factors $(M=3.79$, $\mathrm{SD}=0.59)$, and personal factors $(\mathrm{M}=3.73, \mathrm{SD}=0.61)$. Overall, all the factors yielded a mean of $3.94(\mathrm{SD}=0.42)$. These findings implied that remuneration and conditions of service factor was 
British Journal of Education

Vol.8, Issue 3, pp.76-96, March 2020

Published by ECRTD- UK

Print ISSN: ISSN 2054-6351

Online ISSN: ISSN 2054-636X

dominant in the perception of the teachers, followed by school environment while personal factors were least prevalent factor that affects teacher attrition. The results indicated that teachers perceived a blend of factors that is likely to inform their decision to quit teaching. Based on the 5-point Likert scale used where the average was $3.0(1+2+3+4+5 / 5)$, it could be noticed that all the components of the factors as well as the overall factor were above the mean which implies that all the facets of factors and the overall were common in the minds of the teachers.

The interview data in relation to the first research question asked the respondents to outline reasons that are likely to inform their decision to quit teaching. One of the teachers responded that:

My salary is a very demotivating factor to my job as a teacher. My take home salary cannot actually take me home. At the end of the month if you take out the cost of utilities, rent and even transport fares from your salary, you would be left with nothing to even save for unseen challenges that may happen so sir I think the salaries would be one of the major reasons to stop teaching (Teacher \#3).

Another teacher also remarked:

Apart from our salary, I think I am likely to stop teaching because of the poor state of most of the classrooms. Our classrooms are mostly overpopulated coupled with the fact that there are no furniture to accommodate students. This often makes it difficult to effectively manage the students. These conditions makes our job as teachers very frustrating and challenging. (Teacher \#2).

Reacting to his view on the factors that will cause him to stop teaching, a teacher had this to say:

Deplorable classroom environment, heavy workload often resulting in stress, inadequate instructional resources, unfriendly working relationships that exist in teaching, delayed promotions and a host of other factors are the reasons behind my decision to quit teaching if I had a better alternative. (Teacher \#4).

Another teacher commented that:

The low level of recognition of teachers by government officials, gross disrespect for teachers, low level of prestige or status for teachers make me feel like quitting teaching. You sometimes hear government officials say as for teachers, their reward is in heaven. This makes me angry and annoyed but for the love of the children, we are humbled to teach them (Teacher \#5).

The analyses of the qualitative data showed that the factor(s) that affect teacher attrition is diverse. The findings of this study is consistent with previous studies (Brok, et al., 2017; Aglomasa \& Avoke, 2013; Buchanan, et al., 2013) where their findings revealed teachers poor salaries, poor working environment, indiscipline towards teachers, inadequate induction 
British Journal of Education

Vol.8, Issue 3, pp.76-96, March 2020

Published by ECRTD- UK

Print ISSN: ISSN 2054-6351

Online ISSN: ISSN 2054-636X

programs and poor working conditions to be the main factors influencing teacher attrition. While some cited remuneration and salaries, others recounted on the poor working conditions and other personal reasons to be the factors that are likely to inform their decision to quit teaching. Accordingly, measures are needed to reverse the increasing trend of teacher attrition in Ghana.

Research Question 2: What retention strategies could be used to enhance public basic school teacher retention in the Atiwa District?

This research question investigated the retention strategies that could be implemented in the study area to reduce teachers turnover intentions in the study area and the results are presented in Table 2. The previous research question have discussed the various causes of teacher attrition and as a result, the respondents opined the following measures as strategies that could be employed in an attempt to reduce teacher turnover intentions.

Table 2: Summary of Retention Strategies

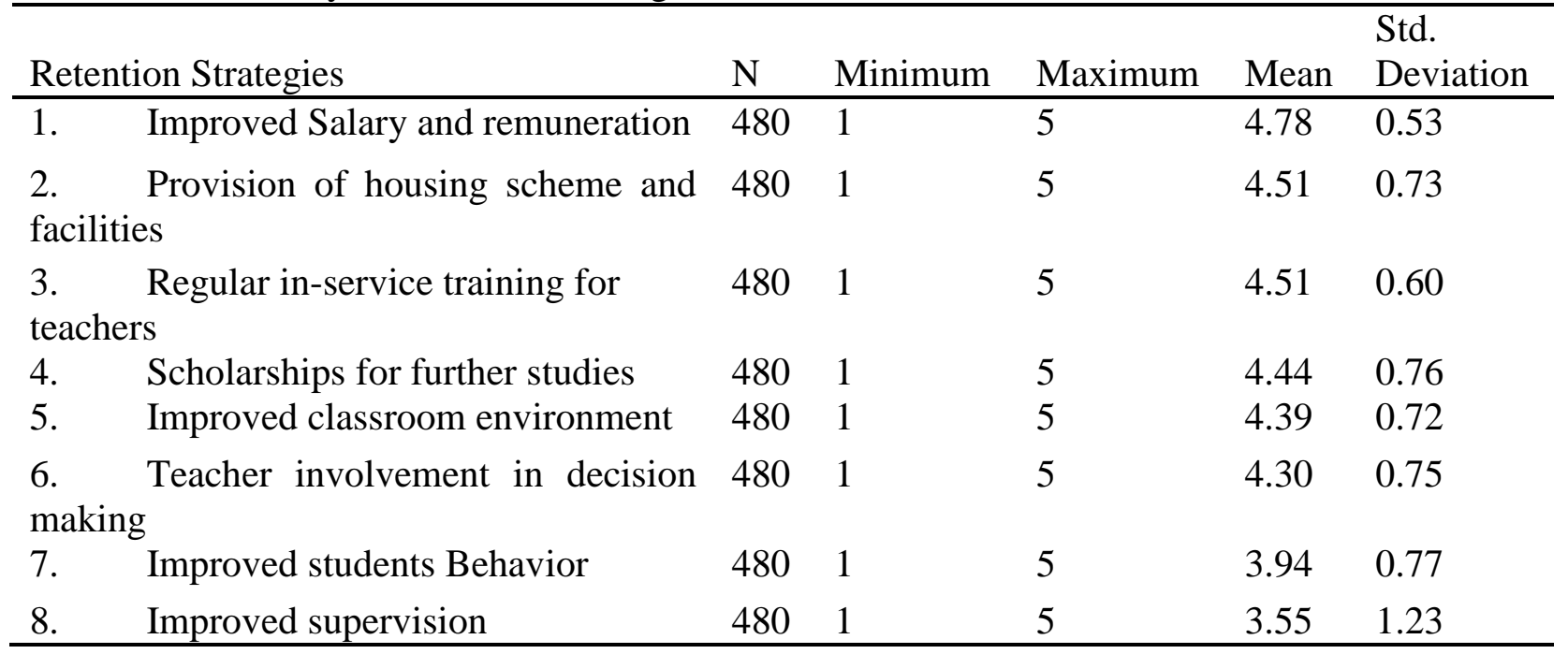

Source: Survey Data, 2019

The information in Table 2 revealed that the participants perceived all the measures highlighted in this study as ways to reduce teacher turnover intentions. However, the participants rated highest on improved salary and remuneration $(\mathrm{M}=4.78, \mathrm{SD}=0.53)$, followed by provision of housing scheme and facilities $(\mathrm{M}=4.51, \mathrm{SD}=0.73)$, regular in-service training for teachers $(\mathrm{M}=4.51, \mathrm{SD}=0.60)$, scholarships for further studies $(\mathrm{M}=4.44, \mathrm{SD}=0.76)$, improved classroom environment $(\mathrm{M}=4.39, \mathrm{SD}=0.72)$, teacher involvement in decision $(\mathrm{M}=4.30, \mathrm{SD}=0.75)$, improved students behaviour $(\mathrm{M}=3.94, \mathrm{SD}=0.77)$ while improved supervision $(\mathrm{M}=3.55$, $\mathrm{SD}=1.23$ ) was the least preferred measure. From these results, it could be observed that improved salary and remuneration, provision of housing scheme and facilities, regular in-service training, scholarships for further studies and improved classroom environment were the most preferred measures that could be put in place to overcome the turnover intentions amongst teachers in the study area. 
British Journal of Education

Vol.8, Issue 3, pp.76-96, March 2020

Published by ECRTD- UK

Print ISSN: ISSN 2054-6351

Online ISSN: ISSN 2054-636X

The qualitative data explored the views of teachers on what could be done to overcome the turnover intentions amongst teachers. In suggesting what could be done, a teacher remarked improved salary:

In my view, the salaries of teachers should be improved to match with others with the same qualifications but working in other sector. In Ghana, a degree holder who works in other sector other than teaching earns more than a teacher with similar qualification. Why should this happen? As teachers we also function as counsellors by giving students advice to be successful in life. We also mark exercises, assignments etc. and we are not given any allowance. Our salaries need to be given the rapt attention it deserves (Teacher \#5).

Another teacher called for the reduction in the class size thus:

In my opinion I think school authorities and the government should as a matter of urgency put in place measures to reduce the large class sizes that we are facing. To me providing more infrastructure and more teachers need to be recruited to augment the current staff. Additionally, I think other measures like the use of technology could help reduce the challenges of large size class, I'm convinced that the surest way to tackle the challenge of teacher attrition is to reduce the class size to make it manageable. This would help to reduce our workload, make teaching enjoyable and effective (Teacher \#3)

It emerged from the interview data that teachers favour improved classroom environment for effective teaching and learning as one of the teachers lamented thus:

Sir I sometimes do not understand why in the $21^{\text {st }}$ century our classrooms still don't have access to electricity. As a teacher I sometimes want to do incorporate ICT in my teaching to deal with the large class sizes we are experiencing but I am confronted with no electricity in my school. So to make us happy and still stay in teaching, our classrooms should be provided with electricity (Teacher \#7).

Provision of housing scheme for teachers was fingered to be one of the ways to keep teachers in teaching. On this point, one of the teachers remarked:

For me I think teachers need housing scheme and some kind of insurance. Our salaries as teachers will not permit you to do some savings let alone you thinking of building. It is not easy so if the government can even use part of our pension as mortgage and give us a house, I think, it will be laudable. With this, there should be criteria, say, if a teacher teaches for 15 years, he or she should qualify for house. Again, on insurance, look at this age and time we are still using the chalk and the black board. Many teachers on retirement have suffered eye related challenges due to this. So if authorities would not replace black board and chalk, then give us insurance (Teacher \#8). 
British Journal of Education

Vol.8, Issue 3, pp.76-96, March 2020

Published by ECRTD- UK

Print ISSN: ISSN 2054-6351

Online ISSN: ISSN 2054-636X

It was also captured that regular in-service training for teachers could be one of the strategies to get teachers in the classroom. This was captured in the statement:

I have been teaching for the past five years and I have not been to any job training. We need to be attending workshops and seminars regularly to update our knowledge and skills for improved teaching and learning. This would make us to be in shape as teacher (Teacher \#9).

Aside the call for the regular in-service training for teachers, another teacher lamented on the state of promotion of teachers:

I have been a teacher for seven years now and I have not been promoted yet. Some of my friends have been teaching for more than eight years and are yet to be promoted. Promotions in the teaching service in Ghana are very irregular unlike other professions. So we are pleading that promotions in the Ghana Education should be regular and also be devoid of favoritism (Teacher \#10).

The statements stressed that teacher retention would be enhanced if attention is given to their worries such as improved remuneration and conditions of service of teachers, reduction in class sizes, provision of housing scheme, provision of electricity supply in the schools, regular job training and opportunity for continuous professional development of teachers. The findings of this study is in agreement with previous studies (Makisio, 2016; MChia, 2013; \& Northouse, 2013) where proposals such as improvement in working conditions of teachers, increased salary and other benefits, provision of housing schemes for teachers, improvement of teachers working conditions, provision of career development opportunities apposite leadership style and swift and regular promotions of teachers have been advanced in trying to get teachers in the classroom were among the retention strategies put forward to retain teachers.

Research Question Three

To what extent does factors (sex, age, rank, academic qualification, marital status, teaching experience, level of teaching) influence teacher attrition in public basic schools in the Atiwa District?

The third research question investigated the extent to which demographic variables such as sex, age, rank, academic qualification, marital status, teaching experience, and level of teaching influence teacher attrition in the public basic schools in the Atiwa District. The multiple regression was employed to provide answers to this research question, and the results are presented in Table 3. 
British Journal of Education

Vol.8, Issue 3, pp.76-96, March 2020

Published by ECRTD- UK

Print ISSN: ISSN 2054-6351

Online ISSN: ISSN 2054-636X

Table 3: Model Summary of Multiple Regression Results for Demographic Factors Influencing Teacher Attrition

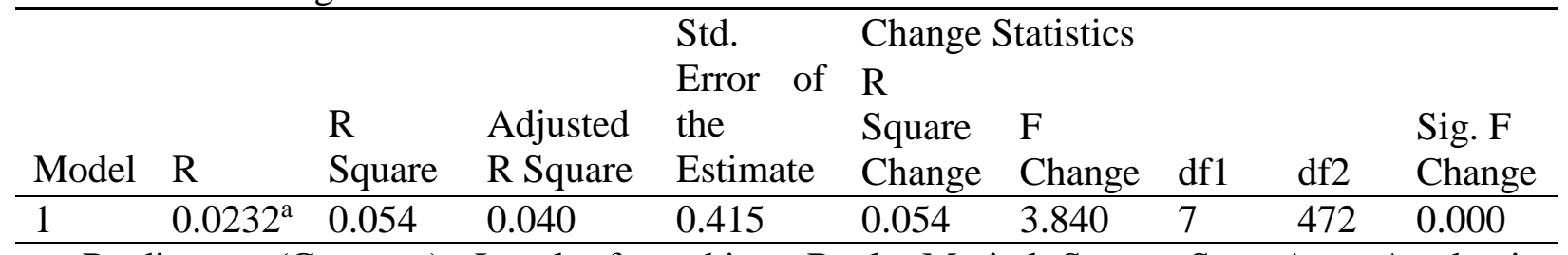

a. Predictors: (Constant), Level of teaching, Rank, Marital Status, Sex, Age, Academic Qualification, Years of Teaching Experience

b. Dependent Variable: Attrition Factors

The multiple regression results in Table 3 revealed that teachers' demographic variables such as marital status, years of teaching experience and level of teaching collectively accounted for $5.4 \%$ to teacher attrition which was considered to be statistically significant $[\mathrm{F}(7,472)=3.840$, $\mathrm{p}<0.05]$.

Table 4: $\quad$ ANOVA Results for Demographic Variables and Factors Influencing Teacher Attrition

\begin{tabular}{|c|c|c|c|c|c|}
\hline Model & $\begin{array}{l}\text { Sum } \\
\text { Squares }\end{array}$ & Df & Mean Square & $\bar{F}$ & Sig. \\
\hline 1 Regression & 4.625 & 7 & 0.661 & 3.840 & $0.000^{\mathrm{b}}$ \\
\hline Residual & 81.224 & 472 & 0.172 & & \\
\hline Total & 85.849 & 479 & & & \\
\hline
\end{tabular}

a. Dependent Variable: Attrition Factors

b. Predictors: (Constant), Level of teaching, Rank, Marital Status, Sex, Age, Highest Academic Qualification, Years of Teaching Experience

This result implied that other factors not included in this study were responsible for $94.6 \%$ influence for teacher attrition. Based on these results, it was evident that together, these factors were good predictors of teacher attrition in the public basic school in the Atiwa District of Ghana. The study further examined the influence of each predictor to teacher attrition, and the results are presented in Table 5. 
British Journal of Education

Vol.8, Issue 3, pp.76-96, March 2020

Published by ECRTD- UK

Print ISSN: ISSN 2054-6351

Online ISSN: ISSN 2054-636X

\begin{tabular}{|c|c|c|c|c|c|c|}
\hline \multirow{2}{*}{\multicolumn{2}{|c|}{ Model }} & \multicolumn{2}{|c|}{$\begin{array}{l}\text { Unstandardized } \\
\text { Coefficients }\end{array}$} & \multirow{2}{*}{$\begin{array}{l}\text { Standardized } \\
\text { Coefficients } \\
\text { Beta }\end{array}$} & \multirow[b]{2}{*}{$\mathrm{t}$} & \multirow[b]{2}{*}{ Sig. } \\
\hline & & $\mathrm{B}$ & Std. Error & & & \\
\hline & (Constant) & 4.071 & 0.223 & & 18.257 & 0.000 \\
\hline & Sex & -0.048 & 0.041 & -0.057 & -1.175 & 0.241 \\
\hline & Marital Status & 0.158 & 0.043 & 0.227 & 3.697 & 0.000 \\
\hline & Age & 0.032 & 0.035 & 0.061 & 0.908 & 0.364 \\
\hline & Academic Qualification & -0.061 & 0.039 & -0.099 & -1.567 & 0.118 \\
\hline & Rank & -0.039 & 0.021 & -0.130 & -1.828 & 0.068 \\
\hline & Years of Teaching Experience & -0.092 & 0.028 & -0.229 & -3.229 & 0.001 \\
\hline & Level of teaching & 0.097 & 0.041 & 0.114 & 2.373 & 0.018 \\
\hline
\end{tabular}

Source: Survey Data, 2019

The results in Table 5 showed that teachers' marital status $(\beta=0.227, \mathrm{t}=3.697, \mathrm{p}<0.05)$, years of teaching experience $(\beta=-0.229, \mathrm{t}=-3.229, \mathrm{p}<0.05)$, and level of teaching $(\beta=0.114, \mathrm{t}=2.373$, $\mathrm{p}<0.05)$ individually contributed significantly to teacher attrition while the contribution of sex $(\beta=-0.057, \mathrm{t}=-1.175, \mathrm{p}>0.05)$, age $(\beta=0.061, \mathrm{t}=0.908, \mathrm{p}>0.05)$, academic qualification $(\beta=-0.099$, $\mathrm{t}=-1.567, \mathrm{p}>0.05)$, and years of teaching experience $(\beta=-0.229, \mathrm{t}=-3.229, \mathrm{p}>0.05)$ were not significant. In order of magnitude, it was revealed that marital status contributed most to teacher attrition, followed by years of teaching experience, and level of teaching. Based on these findings, it was concluded that marital status, years of teaching experience, and level of teaching were the major factors that influenced teacher attrition in the public basic schools in Atiwa District of Ghana. This finding resonates with previous studies (Nkang, 2008; Makisio, 2016; Chandler, et al., 2004) where teachers' marital status, years of teaching experience, and level of teaching significantly predict their attrition. However, this finding disagrees with Efanga et al., (2014) and Stinebrickner (2002) who found no significant statistically significant difference between teachers' years of teaching experience and their quit intentions. Additionally, this study has established that sex, age, and rank did not influence attrition as this is consistent Shaheen and Mahmood (2016) and Strydom et al., (2012) but is however inconsistent with Makisio (2016) where attrition of teachers was influenced significantly by gender, age, and academic qualification.

\section{Test of the Study's Hypotheses}

Hypothesis 1

$\mathrm{H}_{01}$ : Teachers' demographic variables will not statistically significantly predict their perception of the retention strategies.

In testing this hypothesis, the multiple regression was used where teachers demographic variables such as (sex, age, rank, academic qualification, marital status, teaching experience, and level of teaching) were used as predictors of the retention strategies and the results are shown in Table 6. 
British Journal of Education

Vol.8, Issue 3, pp.76-96, March 2020

Published by ECRTD- UK

Print ISSN: ISSN 2054-6351

Online ISSN: ISSN 2054-636X

Table 6: Model Summary Results for Demographic Variables and Retention Strategies

$$
\text { Change Statistics }
$$

\begin{tabular}{llllllllll} 
Model & $\mathrm{R}$ & $\mathrm{R}^{2}$ & $\Delta \mathrm{R}^{2}$ & $\begin{array}{l}\text { SE of the } \\
\text { Estimate }\end{array}$ & $\begin{array}{l}\mathrm{R} 2 \\
\text { Change }\end{array}$ & $\begin{array}{l}\mathrm{F} \\
\text { Change }\end{array}$ & df1 & df2 & $\begin{array}{l}\text { Sig. } \\
\text { Change }\end{array}$ \\
\hline 1 & $0.333^{\mathrm{a}}$ & 0.111 & 0.097 & 0.390 & 0.111 & 8.387 & 7 & 472 & 0.000 \\
\hline
\end{tabular}

a. Predictors: (Constant), Level of teaching, Rank, Marital Status, Sex, Age, Academic Qualification, Years of Teaching Experience

b. Dependent Variable: Retention Strategies

In Table 6, the multiple regression results showed that there was a positive correlation between the predictors (sex, age, rank, academic qualification, marital status, teaching experience, and level of teaching) and retention strategies $(\mathrm{R}=0.333)$. The information disclosed that all the demographic variables contributed $11.1 \%$ variance to the proposed retention strategies. It is evident from the results that there was about $1.4 \%$ difference in the population variance $\left[\mathrm{R}^{2}\right.$ $\left.(0.111)-\Delta \mathrm{R}^{2}(0.097)\right]$. The ANOVA test results in Table 7 showed that the multiple regression was significant $[\mathrm{F}(7,472)=8.387, \mathrm{p}<0.05]$. This implied that together, the demographic variables were good predictors of the proposed retention strategies.

Table 7: ANOVA Results for Demographic Variables and Retention Strategies

\begin{tabular}{lllllll}
\hline & & Sum & of & & Mean & \\
Model & Squares & & Df & Square & F & Sig. \\
\hline 1 Regression & 8.918 & 7 & 1.274 & 8.387 & $0.000^{\mathrm{b}}$ \\
Residual & 71.697 & 472 & 0.152 & & \\
$\quad$ Total & 80.616 & 479 & & & \\
\hline
\end{tabular}

a. Dependent Variable: Retention Strategies

b. Predictors: (Constant), Level of teaching, Rank, Marital Status, Sex, Age, Academic Qualification, Years of Teaching Experience

The study further examined the contribution of each of the demographic variables to retention strategies, and the results were shown in Table 8. 
British Journal of Education

Vol.8, Issue 3, pp.76-96, March 2020

Published by ECRTD- UK

Print ISSN: ISSN 2054-6351

Online ISSN: ISSN 2054-636X

\begin{tabular}{|c|c|c|c|c|c|}
\hline \multirow[t]{2}{*}{ Model } & \multicolumn{2}{|c|}{$\begin{array}{l}\text { Unstandardized } \\
\text { Coefficients }\end{array}$} & \multirow{2}{*}{$\begin{array}{l}\text { Standardized } \\
\text { Coefficients } \\
\text { Beta } \\
\end{array}$} & & \multirow[b]{2}{*}{ Sig. } \\
\hline & $\overline{\mathrm{B}}$ & Std. Error & & & \\
\hline 1 (Constant) & 4.353 & 0.209 & & 20.778 & 0.000 \\
\hline Sex & -0.115 & 0.039 & -0.140 & -2.977 & 0.003 \\
\hline Marital Status & 0.121 & 0.040 & 0.180 & 3.022 & 0.003 \\
\hline Age & -0.044 & 0.033 & -0.087 & -1.348 & 0.178 \\
\hline Academic Qualification & 0.065 & 0.036 & 0.109 & 1.783 & 0.075 \\
\hline Rank & -0.054 & 0.020 & -0.184 & -2.668 & 0.008 \\
\hline Years of $\mathrm{T}$ & 0.006 & 0.027 & 0.016 & 0.238 & 0.812 \\
\hline Level of teaching & 0.070 & 0.038 & 0.085 & 1.827 & 0.068 \\
\hline
\end{tabular}

The results in Table 8 showed that the contribution of sex $(\beta=-0.140 \mathrm{t}=-2.977, \mathrm{p}<0.05)$, marital status $(\beta=0.180, \mathrm{t}=3.022, \mathrm{p}<0.05)$, and $\operatorname{rank}(\beta=-0.184, \mathrm{t}=-2.668, \mathrm{p}<0.05)$ made significant contribution to retention strategies while the contribution of age $(\beta=-0.087, t=-1.348, p>0.05)$, academic qualification $(\beta=0.109, \mathrm{t}=1.783, \mathrm{p}>0.05)$, years of teaching experience $(\beta=0.016$, $\mathrm{t}=0.238, \mathrm{p}<0.05)$, and level of teaching $(\beta=0.085, \mathrm{t}=1.827, \mathrm{p}<0.05)$ did not contribute significantly to retention strategies. In essence, the analysis established that sex, marital status and rank of teachers would boost retention strategies among the teachers by $0.140,0.180$ and 0.184 scores respectively. Implicitly, retention strategies to get teachers remain in the teaching profession would improve if these demographic characteristics needs of the teachers are enhanced. Therefore, the null hypothesis that "Teachers' demographic variables will not statistically significantly predict their perception of the retention strategies." was not supported while the alternative hypothesis that "Teachers" demographic variables will statistically significantly predict their perception of the retention strategies" was supported. This finding corroborate with previous studies (Efanga, et al., 2014; Nkang, 2004) where these variables significantly influenced retention. Contrarily, this finding disagrees with Crossman and Harris (2006), George, et al., 2008) and Otube (2004) where they disclosed no statistically significant difference between sex, marital status and rank and teachers' retention.

\section{RESEARCH IMPLICATIONS}

The findings of this study have implications for teacher retention if stakeholders desire to reduce attrition among teachers so as to ensure quality education delivery at Atiwa District. Conscious efforts to improving remuneration and condition of service factors, school environment related factors and personal factors are likely to ease the turnover intentions among teachers so as to boost teachers' retention for improved academic performance. Importantly, given the fact that generally teachers are unhappy working in the Atiwa District, and they will leave the district when they get the chance, it could be noted that teacher retention is a challenge due to frequent transfers desires, hence it is expected that efforts are made to retain teachers in the district so as to derive the benefits therein. As observed by researchers the direct costs of attrition include 
British Journal of Education

Vol.8, Issue 3, pp.76-96, March 2020

Published by ECRTD- UK

Print ISSN: ISSN 2054-6351

Online ISSN: ISSN 2054-636X

replacement, hiring and selection process, expenses of temporary staff, and the wasted time, and indirect costs include decline in staff's morale, extra pressure on remaining teachers, decline in academic performance and the lost knowledge from the organization. Staff retention should therefore be the concern of all relevant education stakeholders in the Atiwa District at all times if educational goals and objectives are to be realized.

\section{CONCLUSIONS AND RECOMMENDATIONS}

The study set off on the conviction that teacher attrition is an unending phenomenon due to a plethora of reasons. It is therefore expected that these factors are explored so as to forestall any adverse consequences. Indeed, literature has documented several factors that trigger this phenomenon. For instance, this study explored three factors: remuneration and conditions of service, school environment related factors and teachers' personal factors. Even though one or more of these factors could be dominant in the reasoning of the teachers, it is important that all the factors outlined in the study are dealt with. Accordingly, remuneration and conditions of service and school environment should be improved since these are among the top reasons discovered as being behind teacher turnover. Again, it was evident from the findings that improved salaries and remuneration, provision of housing scheme, regular in-service training, scholarships for further studies, improved classroom environment and teachers involvement in decision making were highly favored by the teachers and was linked to the retaining teachers in the study area. This implies that, if stakeholders desire to reduce attrition rate so as realize improved educational environment, then retention strategies outlined in this study should prioritized because they are most likely to boost teacher retention. It is pertinent to point out that the choice of retention strategies is determined by various factors such as teachers' sex, marital status and rank. Hence, in the determination of retention strategies, it is expected that one considers these factors, and choose a strategy that is consistent with them. In essence, retention strategies are contingent on these factors, hence efforts aimed at retaining teachers will flop with one is unable to pay attention to these factors. In effect, retention strategies and the factors that influence the choice of these strategies are bedfellows, and should be considered jointly. It is worth to note that teachers' demographic factors like age, academic qualification, years of teaching experience and level of teaching do not matter in the choice of retention strategies in the study area. Therefore, in rolling out retention strategies for teachers in the study area attention should not be paid to these factors.

\section{References}

Aglomasa, T., \& Avoke, M, (2013). An analysis of factors accounting for teacher attrition in Ghana: a focus on special schools. African Journal of Interdisciplinary Studies, 6(1), 2437.

Ahuja, M. K., Chudoba, K. M., Kacmar, C. J., McKnight, D. H. \& George, J. F. (2007). It Road Warriors: Balancing work-family conflict, job autonomy, and work overload to mitigate turnover intentions. MIS Quarterly, 31(1), 1-17. 
British Journal of Education

Vol.8, Issue 3, pp.76-96, March 2020

Published by ECRTD- UK

Print ISSN: ISSN 2054-6351

Online ISSN: ISSN 2054-636X

Ahuja, M., K., Chudoba, K., M., Kacmar, C., J., McKnight, D., H., \& George, J. F. (2007). It road warrior: Balancing work-family conflict, Job autonomy and work overload to mitigate turnover intentions. MIS Quarterly, 31(1), 1-17.

Allen, M. B. (2005). Eight questions on teacher recruitment and retention: What does the research say? Education commission of the states teaching quality research reports, September 2005. Retrieved from http://www.ecs.org/html/educationIss ues/TeachingQuality/TRRreport/ home/TeacherRecruitmentRetention.pdf.

Alliance for Excellent Education (2008). What keeps good teachers in the classroom? Understanding and reducing teacher turnover. Washington, DC: Alliance for Excellent Education.

Ariko, C. O. (2009). Factors influencing secondary school teacher transfer requests in Suba District, Kenya: Analytical Assessment. Available: www.interesjournals.org/ER (March 3, 2012).

Asamoah-Gyimah, K., \& Duodu, F. (2007). Introduction to research methods in education. University of Education, Winneba: Institute for Educational Development and Extension (IEDE).

Avoke, M. (2013). Some historical perspective in the development of special education in Ghana. European Journal of Special Needs 16(1), 29-40

Babbie, E., (2007). The practice of social research ( $1^{\text {th }}$ ed.). USA: Thomas Wadsworth.

Bergman M. M. 2008. Introduction: whither mixed methods? In M. M. Bergman (ed.), Advances in Mixed Methods Research. London: Sage: 1-7.

Black, K. (2009). Business statistics: Contemporary decision making (6 $6^{\text {th }}$ ed.). Jefferson City: John Wiley and Sons.

Borman, G., \& Dowling, M. (2008). Teacher attrition and retention: a meta-analytic and narrative review of the research. Review of Educational Research, 78, 367-409.

Braun, V. \& Clarke, V. (2006). Using thematic analysis in psychology. Qualitative Research in Psychology, 3(2). pp. 77-101.

Brok, P. D., Wubbels, T., \& Tartwij, J. V. (2017). Exploring beginning teachers' attrition in the Netherlands. Journal of Teachers and Teaching: theory and practice, 23(8), 881-895

Buchanan, J., Prescott, A., Schuck, S., Aubusson, P., Burke, P., \& Louviere, J. (2013). Teacher retention and attrition: views of early career teachers. Australian Journal of Teacher Education, 38(3), 112-129.

Burns, N., \& Grove, S. K. (2011). Understanding nursing research - Building an evidence-based practice $\left(5^{\text {th }} \mathrm{ed}\right)$. Maryland Heights, Missouri: Elsevier Saunders.

Candle. J. (2010). Factors affecting teacher turnover in private secondary schools in Wakiso District. (Master of Science Thesis, Makerere University- Kampala).

Chandler, K., Luekens, M., Lyter, D., \& Fox, E. (2004). Teacher attrition and mobility: Results from the teacher follow-up survey, 2000-01. Washington, DC: National Center for Education Statistics.

Charlton, D. \& Kritsonis, W. (2010). Human resource management: Accountability, reciprocity and the nexus between employer and employee. National Forum of Educational Administration and Supervision Journal, 26(3), 46-61. 
British Journal of Education

Vol.8, Issue 3, pp.76-96, March 2020

Published by ECRTD- UK

Print ISSN: ISSN 2054-6351

Online ISSN: ISSN 2054-636X

Darling-Hammond, L., \& Sykes, G. (2003). Wanted: A national teacher supply policy for education: The right way to meet the highly qualified teacher challenge. Education Policy Analysis Archives, 11(3), 66-82

Dehaloo, G. (2011). The motivation and job satisfaction of secondary school teachers in KwaZulu- Natal: An education management perspective. (Unpublished Doctoral Thesis, University of South Africa).

Dibble, S. (1999). Keeping your valuable employees: Retention strategies for your organisation. Canada: John Wiley \& Sons, Inc.

Efanga, S. I. (2007). Demographic variables and its influence on conflict management in Akwa Ibom State secondary schools. Journal of Education and Society 5(2), 48-52.

Efanga, S. I., Ikpe, U. G., \& Idante, G. O. (2014). Influence of demographic variables on teachers' willingness to stay on the teaching profession in Akwa Ibom State of Nigeria. International Journal of Humanities Social Sciences and Education 1(10): 41-46.

George, D., \& Mallery, P. (2003). SPSS for Windows step by step: A simple guide and reference. 11.0 update (4th ed.). Boston: Allyn \& Bacon.

George, E., Louw, D. \& Badenhorst, G. (2008). Job satisfaction among urban secondary school teachers in Namibia. South African Journal of Education, 28, 135-154.

Ghana Business News 2013 retrieved on 30th October 2013 from www.ghanabusinessnews.com

GNAT- TEWU. (2009). Teacher attrition in pre-tertiary education system in Ghana: Results of a national survey of teachers in 2009. Retrieved from http;www.ghana.newsagency.org/details/edu on the 15th March, 2014.

Harmsen, R., Helmz-Lorenz, M., Maulana, R., \& van Veen, K. (2017). The relationship between beginning teachers' stress causes, stress responses, teacher behaviour and attrition. Paper presented at the Annual meeting of the American Educational Research Association, San Antonio, Texas, and April 26-May 2.

Hernandez, P. (2007). Teacher efficacy: A construct validation. Journal of Educational Psychology, 76, 569-582.

Hong, J. Y. (2010). Pre-service and beginning teachers' professional identity and its relation to dropping out of the profession. Teaching and Teacher Education, 26, 1530-1543.

Horng, E. L. (2005). Poor working conditions make urban schools hard-to-staff. UC accord public policy Series, PB-010-0305. University of California, Los Angeles, California. Retrieved from http://ucaccord.gseis.ucla.edu/publications/pubs/pb-010-0305.pdf

Ingersoll, R. (2001). Teacher turnover and teacher shortages: An organizational analysis. American Educational Research Journal, 38(3), 499-534.

Kain, E. (2011). High teacher turnover rates are a big problem for America's public schools. Available: www.forbes.com/sites/erikkain/2011/03/08/ high teacher turnover rates are a big problem for America's public schools/ (July 13, 2013).

Leacock, C., Warrican, S., Rose G. (2009). Research methods for inexperienced researchers. Kingston Jamaica: Ian Randle Publishers.

Levy, J. (2012). Investing in the future: Setting educational priorities in the developing world. Paris:UNESCO:IIEP. 
British Journal of Education

Vol.8, Issue 3, pp.76-96, March 2020

Published by ECRTD- UK

Print ISSN: ISSN 2054-6351

Online ISSN: ISSN 2054-636X

Luekens, M.T., Lyter, D. M., \& Fox, E. E. (2004). Teacher attrition and mobility: Results from the teacher follow-up survey, 2000-01. Washington, D.C.: National Center for Education Statistics. Retrieved from http://www.nces.ed.gov/pubs2004/2004301.pdf.

Mathis, R. \& Jackson, J. (2006). Human Resource Management (1 ${ }^{\text {th }}$ ed.). Mason, OH: Thomson/Southwestern, pp. 524-565.

Mchia L., E. (2013). Factors affecting teachers' turnover in public secondary schools in Ruangwa Rural District Council, (Unpublished Master's Thesis, OPEN University of Tanzania).

McInerney, D. M., Ganotice, F. A., King, R. B., Marsh, H. W., \& Morin, A. J. S. (2015). Exploring commitment and turnover intentions among teachers: What we can learn from Hong Kong teachers. Teaching and Teacher Education, 52, 11-23.

Mireku, D. K. (2002). Demand and supply of basic school teachers in Ghana. National Teacher Education Forum, UCEW, Winneba.

Mulei, K.O., Waita,K. J., Mueni, K. B. Mutune, M. J. \& Kalai, J. (2016). Factors Influencing Teacher Attrition in Public Secondary Schools in Mbooni-East Sub-County, Kenya. International Journal of Education and Research 4(3), 367-382.

Mulkeen, A. (2005). Teachers in Anglophone Africa. The World Bank Washington DC

Ngala, P. N. (2010). Retaining the Graduate Teacher in the Ghana Education Service: (Unpublished Masters of Philosophy thesis, University of Ghana, Legon).

Nkang, I. E., (2004). Gender equity and sustainable development: The case study of higher institutions in Akwa Ibom State. Paper presented at the Annual Conference of National Human Rights Commission.

Nkang, I. E., (2008). Gender equity and sustainable development: The case study of higher institutions in Akwa Ibom State. Paper presented at the Annual Conference of National Human Rights Commission.

Northouse, P. G. (2013). Leadership: Theory and practice, (5th ed). Los Angeles, CA: SAGE.

Okeke, B. S. (2004). Teaching in Nigeria: The Bureaucracy and Professionalism. Enugu: Mercury International Publishing.

Oloruntegbe, K.O. (2011). Teachers' involvement, commitment and innovativeness in curriculum development and implementation. Journal of Emerging Trends in Educational Research and Policy Studies, 2(6), 443-449.

Otube, N. W., (2004). Job motivation of teachers educating learners with special needs in four provinces in Kenya. (Unpublished doctoral dissertation), University of Hamburg.

Owolabi, S. O. (2007).Teacher education in sub-Saharan Africa: Policies and practices. Paper presented at the Development of Teacher Education in Africa Conference. Makarere University, Kampala, Uganda. August 4-6.

Pillen, M. (2013). Professional identity tensions of beginning teachers. Unpublished doctoral dissertation. Eindhoven: ESoE, Eindhoven University of Technology. https://pure.tue.nl/ws/ files/3635118/758172.pdf

Quansah, K. B. (2003). Teacher demand and supply: The next decade. Cape Coast: University of Cape Coast. 
British Journal of Education

Vol.8, Issue 3, pp.76-96, March 2020

Published by ECRTD- UK

Print ISSN: ISSN 2054-6351

Online ISSN: ISSN 2054-636X

Riggs, L. (2013). Why do teachers quit and why do they stay? The Atlantic Monthly 312(3). Retrieved from http://www.theatlantic.com/education/archive/2 013/10/why-do-teachersquit/280699/

Saunders, M., Lewis, P. \& Thornhill, A. (2012). Research methods for business students.5th edition. Harlow: Pearson Education.

Sekaran, U., \& Bougie, R. (2010). Research Methods for Business: A Skill Building Approach ( $5^{\text {th }}$ edition). New Jersey: John Wiley and Sons.

Shaheen, F. \& Mahmood, N. (2016). Demographic variables as determinants of emotional burnout among public school teachers. Journal of Research and Reflections in Education, $10(1), 37-50$.

Smith, K. (2014). One a teacher, always a teacher? Examining teacher attrition in a Norwegian and international Perspective. Application submitted to the Norwegian research council, FINNUT program. Bergen: University of Bergen.

Stinebrickner, T. R. (2002). An empirical investigation of teacher attrition. Economics of Education Review 17 (2): 127-36.

Strydom, L., Nortjé, N., Beukes, R., Esterhuyse, K. \& van der Westhuizen, J. (2012). Job satisfaction amongst teachers at special needs schools. South African Journal of Education, 32, 255-266.

Whitehead, D. \& Annells, M. (2007). Sampling and Collecting data in Qualitative research. Sydney: Mosby-Elsevier.

World Bank (2007). Gender Equity and Development. World Development Reports. Washington D. C. Wright, S. P., Horn, S. P. 